\title{
Does Microfinance Reduce Poverty? The Case of Brazil
}

\author{
Mehran Ramezanali and Djamchid Assadi
}

\begin{abstract}
Main objective of this study is to assess the impact of microcredit on poverty reduction in Brazil. Individuals and informal businesses receiving credit from funding agencies and must demonstrate improvement in their businesses. Mass unemployment, social injustice and deplorable living conditions in some regions of Brazil in global reports show a timid growth. To perform the study used an exploratory research with qualitative approach in the analysis of central bank reports from brazil and other internal reports and also compared with annual reports issued by the united nations. The profile of borrowers is very similar to the profile of entrepreneurs specially when comparing income and geographical location. However, microcredit is important for creating jobs but the government needs to implement other anti-poverty programs and create new assistance projects to achieve satisfactory results.
\end{abstract}

Index Terms-Microcredit, entrepreneurship, poverty, microfinance, financial institutions.

\section{INTRODUCTION}

Two distinct visions suggest two different solutions to the persisting problem of poverty in Brazil. One advocates state intervention for wealth redistribution. The other recommends private entrepreneurial initiatives for wealth creation. Now, after more than a decade of state-based policies supported by a buoyant commodity market that turned out finally to be a kind of Dutch Disease and the worst economic crisis since the 1930s, Brazil seems to consider more private and market-based initiatives for eradicating poverty. This crisis surprisingly provided an unprecedented opportunity for microfinance in a country where it has grown proportionally much less compared to many other countries, especially in Africa and Asia.

As Brazil goes through a political and economic crisis since early 2015, the government disposes less liquidities for social assistance, anti-poverty programs and credit facilities. Under these circumstances, microcredit might provide solutions to the problem of funding (selfemployment) entrepreneurship and unemployment [1]. What is the truth? Does microfinance, and in particular microcredit provide significant positive results to reduce poverty, or does it leave the poor borrowers in unchanged or even worse conditions? The research on hands aims to provide elements of answer to this question of microcredit impact in the particular case of Brazil.

Manuscript received January 11, 2018; revised March 7, 2018.

Mehran Ramezanali is UNIDAVI, Brazil (e-mail: mehran@unidavi.edu.br).

\section{LITERATURE REVIEW}

While small loans among relatives have always existed, Muhammad Yunus created the modern form of it (microfinance) in the mid-1970s in rural Bangladesh. In Yunus's view, microfinance is not about wealth distribution and allocation of funds to the poor. It is rather about providing an economic tool so that the poor independently work their way out of poverty [1]. The Yunus's idea of providing small loans to the financially excluded individuals [2], inspired many in 1970s and 1980s around the world for poverty alleviation. The worldwide renaissance came in with the Microcredit Summit (Global Conference on Microcredit) in Washington in 1997 where representatives from 137 countries considered microcredit as an important instrument for reducing poverty in the world. The Summits defined microcredit as small loans to very poor people for self-employment projects that generate income, allowing them to care for themselves and their families. The term "micro" gave rise to many other micro-products such as savings, insurance, and other financial services to the poor. In 2006, the Norwegian Nobel Committee awarded both Yunus and Grameen the Nobel Peace Prize for upholding microcredit in the struggle against poverty. In addition, many researchers have claimed that microcredit programs alleviate and reduce poverty: [3]-[8]. Controversies have however emerged progressively. Researchers and practitioners showed divergent views on the positive impact of microcredit on poverty eradication and job creation.

Advocates believe microfinance has decreased poverty where it has been massively adopted is initiatives. Microcredit fights poverty, reduces inequalities, and improves the living conditions through solidarity, empowerment and social capital [9]. Definition of poverty as lack of capital, and microcredit as generator of capital [4]. Microcredit as an alternative to the problems arising from the exclusionary globalization produced worldwide [4]. Microcredit models are in line with poverty alleviation and empowerment strategies [3]. A greater impact when microcredit observes a local presence and addresses the needs of female borrowers and their households [5]. The joint use of microcredit and community ties can end to a real economic and social betterment [9].

Critics claim that microfinance has only grown in volume without effectively supporting the poor to earn their way out of poverty. The difficulties of finding studies that provide empirical evidence on positive impact of microfinance on poverty reduction in Pakistan [10], also the minimal impact in Asia [11], challenges for more evidences [12]. Contribution to reducing poverty in the end; however, it is not necessarily the most important factor [13]. Even if microcredit can effectively alleviate the less severe poverty cases, the likelihood that it reduces core poverty is 
considerably smaller [6]. Poverty stands for deprivation of economic, social, physical, environmental, cultural, and political resources that prevent individuals from fulfilling their potential [3]; and corollary, poverty alleviation means increase in income and thereby increase in consumption and assets of individuals who have no productive resources but their bodies and labor [5]. While microfinance covers a wide range of services like credit, savings, insurance, remittance and non-financial services like training, counselling etc. that are provided to the low-income group [7], our focus in this paper is microcredit. To assess the impact of microcredit programs on poverty relief in Brazil, we mainly exploit the official data and reports during the period 2014-2015, and match statistical data provided by the Central Bank of Brazil (BCB) and the Internal Revenue Service.

Doing so, we take into account the controversies on both the indicators and the measurement tools. Researchers should not reduce assessing the impact of microcredit on individuals' welfare but rather on the community [14]. Researchers should use methods such as the Human Development Index (HDI) to simultaneously measures longterm progress in three basic dimensions of human development: healthy life, education and living standards [15]. The autor has compared examples of both negative and positive impacts through scrutinizing the questions asked, the methodologies used, the findings reported and the interpretations provided [16]. He concludes that the primary source of the conflict lies in intra-household power relations [16].

\section{RESEARCH METHODOLOGY}

Our research approach is based on exploratory and qualitative analysis of the data published by the Federal Bank of Brazil and the other indexes about the level of poverty in Brazil. We use that data provide by the Brazilian federal banks report, "Série Cidadania Financeira: Estudos em Educação, Proteção e Inclusão", in specialized in Financial Citizenship and citizen financial rights: financial education, consumer protection, and financial inclusion. This document provides an overview of microcredit in Brazil from the point of view of both borrowers and financial institutions.

The four necessary precondition we consider are: relation between supply and demand of microcredit, institutions supporting microfinance, distribution of microcredit in relation to the distribution of poverty, and the affectation of microloans to entrepreneurial of consumptive. The ex-ante factor is evidently the poverty eradication. In line with the above inquiries, definitions and delimitations, we structure the remaining of the paper as follows.

First, we compare the volume of microcredit and size of (poor) population in Brazil. Second, we review the evolution of institutions in the sector of microcredit. Third, we discuss the distribution of microcredit in comparison to the distribution of poverty in Brazil. Four, we explore the affectation of microloans by borrowers to productive and consumptive purposes. Five, we finally assess of microloans on the alleviation of poverty in Brazil.

\section{A. Do Supply and Demand of Microfinance Correctly Match in Brazil?}

While microfinance has relatively lived a long history in Brazil, its volume remains proportionally modest in comparison with other countries, taking into account the weakened economy and the credit limit.

In 2014, the 1045 institutions that sent their data to the MIX platform reached 111.7 million low-income clients and produced a loan portfolio of $\$ 87.1$ billion with a growth of $+12.6 \%$. The increase in numbers of borrowers has almost tripled compare to 2013 increasing from $+4.8 \%$ to $+14.2 \%$. It is estimated that the rate of growth in the sector for 2015 will be $+10 \%$ for loan portfolio and $+15.8 \%$ for borrowers [17]. At the national level, the microcredit portfolio represents $0.2 \%$ of the value and $0.4 \%$ of the operations of the National Financial System (SFN), respectively amounted to R\$ 5.3 billion, for 3.1 million loans [18]. As the Fig. 1 indicates the loans of microcredit grew from 2011 to 2014 and then entered lightly in a fall.

TABLE I: TOP 10 COUNTRIES BY BORROWERS AND LOAN PORTFOLIO OUTREACH

\begin{tabular}{|c|c|c|c|c|c|}
\hline Rank & Country & Borrowers FY 2014(m) & Borowers growth $(\boldsymbol{\%})$ & GLP FY 2014 (USD) bn & GLP Growth (\%) \\
\hline 1 & India & 39,5 & 28,5 & 7,3 \\
\hline 2 & Peru & 4,1 & 3,5 & 10,1 \\
\hline 3 & Vietnam & 7,7 & 0,5 & 6,9 \\
\hline 4 & Bangladesh & 21,8 & 6,7 & 4,6 \\
\hline 5 & Mexico & 6,0 & 2,8 & 4,7 \\
\hline 6 & Colombia & 2,8 & 5,2 & 6,7 \\
\hline 7 & Ecuador & 1,6 & 13,6 & 4,7 \\
\hline 8 & Bolivia & 1,3 & 0,1 & 1,7 \\
\hline 9 & Cambodia & 2,1 & 13,2 & 8,9 \\
\hline 10 & Brazil & 2,9 & 4,7 & 16,7 \\
\hline
\end{tabular}

Source: Microfinance Barometer 2016.

The default of the total microfinance portfolio is $5.6 \%$ among Individuals (PFs) customers and $5.0 \%$ of the Legal entity or small business (PJs) customers, higher percentages than those found in the Banking Industry $(4.4 \%$ and $1.8 \%$, respectively) [19]. Income commitment of PFs microcredit borrowers is $30.4 \%$. In other words, these people commit $30.4 \%$ of their income on credits in general in SFN (not necessarily only microcredit). The default of micro-credit grantors development agencies is $5.2 \%$ for the PFs and $1.4 \%$ for the PJs. The low rate of default of PJs is largely due to the influence of the largest segment of the grantor for this type of customer, which holds $66.6 \%$ of the portfolio granted by funding agencies to PJs and reports have zero default in microcredit operations (it is mentioned the case of OSCIPs customers, who probably passed on much of the resources for individuals whose default is scarcely credible 
that is zero). The default of microcredit grantors banks is $5.8 \%$ for PFs and $9.4 \%$ in the PJs. The default in microcredit grantors credit unions is $1.3 \%$ for PFs and $1.1 \%$ in the PJs - the smallest of the four segments - and is low for most of the segment's institutions. The default of microcredit grantors SCMs is $9.0 \%$ of PFs and $6.1 \%$ of the PCs.

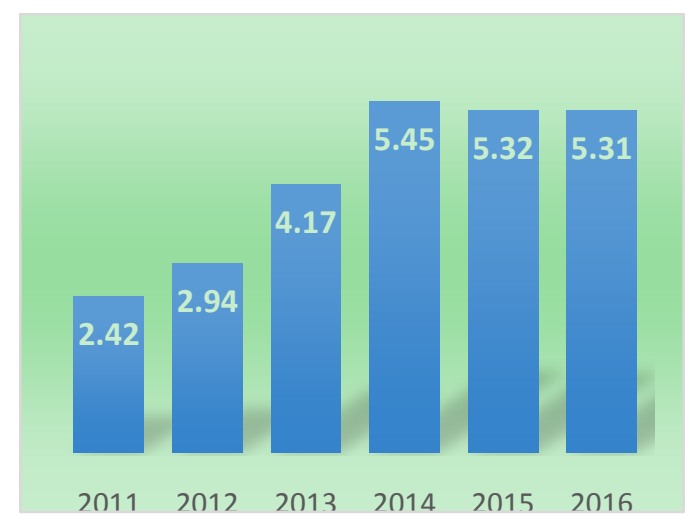

Fig. 1. Amount of microcredit loans in billions Reals (R\$) Source: BACEN-2015

\section{B. Do Institutions Support Microfinance in Brazil?}

Many governments in developing economies have transferred payments to increase financial inclusion. In Latin America and the Caribbean countries, 68 percent of transfer recipients receive the payments into an account. In Brazil: among the 15 percent of adults receiving government transfers, 88 percent receive them directly into an account. In South Africa, a third of adults receive government transfers - and 82 percent of them receive the payments into an account (The Global Findex Database 2014). However, this kind of policy is not sufficient to reduce poverty. For eradicating poverty, states should not only facilitate access to funds for small businesses, but also consolidate the institutional context.

Do institutions back microfinance initiatives to eradicate poverty in Brazil? The principal objective of institutions is to ensure that the microcredit loans lead to incomegenerating effects within the local economy and community [14]. The pertinent institutions consequently support and promote the transactions and interactions between four major actors. Financially excluded individuals (in particular women) who constitute the target. Intermediaries that distribute small loans to and collect repayments from borrowers. Providers and lenders who supply funds. There are also public and private institutions that define and regulate interactions between the mentioned actors.

In this section, we review the developing of public and private institutions that support microcredit in Brazil. Contribution in highlighting the history and observation of the complexity of microcredit in Brazil [8], [9], [13], [20], [21]. Brazil has experienced a long story in microcredit and the urban informal sector of microcredit since the UNO program in 1973 [22]. Since 1990s, both public and private institutions have initiated policies and programs to support microcredit.

In 1996, the National Bank for Economic and Social Development (BNDES), one of the most important Brazilian federal government for fostering credit, created the Popular Productive Credit Program (PCPP) and the
Institutional Development Program (IDP) to support the expansion of microfinance in Brazil. In 1997, another Brazilian public financial institution, the Bank of the Northeast of Brazil, launched a pilot microfinance program, called CrediAmigo. This program became the largest microfinance program in the country and one of the largest in Latin America, both in terms of volume of resources and in terms of number of clients [20].

In 2003, the Brazilian government launched a new program, "pacote de microcrédito" (package of microcredit), based on three pillars of banking, stimulation of microcredit supply, and formation of credit cooperatives [21]. The Brazilian Federal Government has buoyed public policies to provide credit to low-income populations during the two terms of President Fernando Henrique Cardoso (FHC) and the two terms of President Luíz Inácio Lula da Silva [20].

The Brazilian Federal Government created the National Program of Oriented Productive Microcredit (PNMPO) in 2005 with the objective of generating employment and income among micro-entrepreneurs [23]. With the support of the Ministry of Labor and Employment (MTE), the PNMPO created organizations specialized in microcredit (Civil Society Organizations of Public Interest and Credit Societies to Micro-entrepreneur), and other organizations authorized to perform broader financial transactions. By May 2007, the PNMPO had accredited 231 institutions in Brazil [24].

In August 2011, the Brazilian Federal Government reformed the PNMPO and released the -CRESCER $\|$ (GROW) providing credit at lower interest rates to lowincome individuals and micro entrepreneurs within the National Program of -Brazil without Pover yll. Do these and other institutions effectively support the development of microfinance in Brazil? The lack of adequate legislation and regulatory obstacles that prevented growth of the microcredit on a growing scale in Brazil [6].

TABLE II: AMOUNT OF FINANCIAL INSTITUTIONS OPERATING MICROCREDIT AND FIS IN THE SFN, BY SEGMENT

\begin{tabular}{|c|c|c|c|c|c|}
\hline \multirow[b]{2}{*}{ Segment } & \multicolumn{2}{|c|}{$\begin{array}{c}\text { Financial } \\
\text { Institutions (FIs) } \\
\text { operating } \\
\text { microcredit }\end{array}$} & \multicolumn{2}{|c|}{$\begin{array}{l}\text { FIs in National } \\
\text { Financial } \\
\text { System (NFS) }\end{array}$} & \multirow{2}{*}{\begin{tabular}{|c|}
$\%$ \\
$\begin{array}{c}\text { Microcredit } \\
\text { //NFS }\end{array}$
\end{tabular}} \\
\hline & FIs & $\%$ & FIs & $\%$ & \\
\hline Funding agencies & 9 & 8,8 & 15 & 1,1 & 60 \\
\hline Bank & 10 & 9,8 & 153 & 11,2 & 6,5 \\
\hline Credit cooperative & 73 & 71,6 & 1.161 & 85,3 & 6,3 \\
\hline SCM & 10 & 9,8 & 32 & 2,4 & 31,3 \\
\hline Total & 102 & 100,0 & 1.361 & 100,0 & 7,5 \\
\hline
\end{tabular}

Source: Financial Citizenship Series, 2015.

There are four types of microfinance institutions in Brazil (Table II): funding agencies, banks, credit unions (credit cooperative) and microcredit institutions. Three state-owned banks provide more than $80 \%$ of the portfolio value. There are mainly 102 microfinance institutions in Brazil. Only ten financial institutions concentrate the distribution of microcredit in Brazil [18]. They account for most of the value of the portfolio (91.4\%), the number of operations $(94.1 \%)$ and the amount of customers $(93.5 \%)$. Of those 10 , however, only four are active. Three of them are public (Bank of Brazil, Caixa Economica Federal and Banco of Nordeste) and one is private (Santander) [18]. 
In Brazil, the banks providing microcredit are located in major cities. For this reason, few Brazilians have access to microcredit.

TABLE III: MICROCREDIT: VALUE AND NUMBER OF OPERATIONS OF THE TOTAL PORTFOLIO BY SEGMENT

\begin{tabular}{|c|c|c|c|c|}
\hline Segment & Portfolio Value & $\%$ & $\begin{array}{c}\text { Quantity of } \\
\text { Operations }\end{array}$ & $\%$ \\
\hline Funding agencies & 109.142 .659 & 2,0 & 17.792 & 0,6 \\
\hline Bank & 4.879 .957 .516 & 91,4 & 2.943 .231 & 95,0 \\
\hline $\begin{array}{c}\text { Credit } \\
\text { cooperative }\end{array}$ & 327.864 .934 & 6,1 & 121.352 & 3,9 \\
\hline SCM & 22.826 .302 & 0,4 & 15.705 & 0,5 \\
\hline Total & $\mathbf{5 . 3 3 9 . 7 9 1 . 4 1 0}$ & $\mathbf{1 0 0 , 0}$ & $\mathbf{3 . 0 9 8 . 0 8 0}$ & $\mathbf{1 0 0 , 0}$ \\
\hline
\end{tabular}

Source: Financial Citizenship Series, 2015.

\section{Is the Distribution of Microcredit in Brazil Fair and Just?}

In this section, we evaluate whether the distribution of microcredit in Brazil is fair and just by comparing the distribution of microcredit with the distribution of poverty. Distribution of microcredit varies across regions in Brazil. Does it correspond to the distribution of poverty in the country? There are wide disparities in the extent of poverty in Brazil. More than half of all poor Brazilians live in the
Northeast. The Northeast region accounts for $52.1 \%$ of the national portfolio in value. Its share of number of transactions with customers is around $35 \%$.

The average value per transaction in this region is $\mathrm{R}$ $\$ 3,350$, almost $50 \%$ above the national average, which is $\mathrm{R}$ $\$ 2,248$. All other regions have average below the national average. The Southeast is the second largest microcredit portfolio, accounting for $22.6 \%$ of the national value - well below the Northeast portfolio. However, the Southeast region has better infrastructure, number of industries and economic position, has also the largest number of operations and customers in Brazil: 36.4\% of national participation, $1.5 \%$ above the Northeast, and the lowest average value per transaction ( $\mathrm{R} \$ 1,397)$.

\section{How do Borrowers Affect the Microloans?}

One cannot expect that microloans significantly eradicate poverty if borrowers do not affect them to productive wealth generating ventures. How do borrowers affect the microcredits they receive? The following table shows that borrowers are predominately individuals, and not legal entities, firms, which might recourse to loans for development purposes.

TABLE IV: MICROCREDIT BY TYPE OF CUSTOMER AND REGION, (\%)

\begin{tabular}{|c|c|c|c|c|c|c|}
\hline & Center west & Northeast & North & Southeast & South & Brazil \\
\hline Individual & 94,5 & 99,5 & 97,9 & 95,6 & 79,9 & 94,8 \\
\hline Legal entity & 5,5 & 0,5 & 2,1 & 4,4 & 20,1 & 5,2 \\
\hline
\end{tabular}

The following figure indicates how borrowers affect microloans between different purposes. It shows that individuals mainly affect the loans to housing.

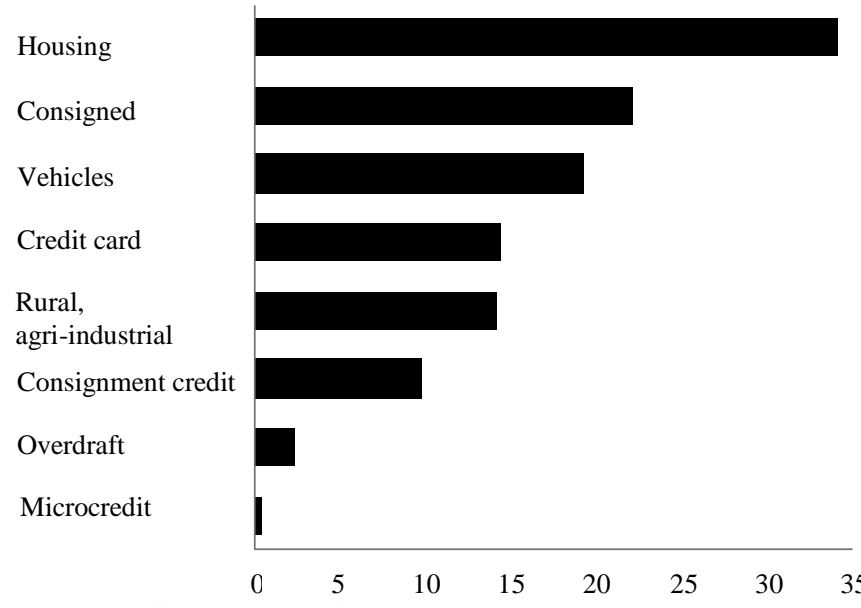

Fig 2. Different sources of loans e credit. Source: Série Cidadania Financeira, 2015.

Should microcredits alleviate poverty, borrowers might affect them to entrepreneurial purposes than consumptive ones. The following figures show the evolution of firm creation in Brazil. Entrepreneur as a creative individual who detects business opportunities in his/her environment and sets to achieve goals [25]. Microenterprises are mainly concentrated around traditional commerce in Brazil [26]. Lower initial capital requisite, minor qualification requirement, simplified physical structure and ability to develop the activity at home explain this phenomenon. 47.8 percent of established entrepreneurs in 2014 had annual revenues of up to $\mathrm{R} \$ 12,000,39.4$ percent from $\mathrm{R} \$ 12,000$ to $\mathrm{R} \$ 36,000$ and $6.3 \%$ from $\mathrm{R} \$ 36,000$ and $\mathrm{R} \$ 60,000$, totaling 93.5 percent to $\mathrm{R} \$ 60,000$. [18].

Of the 23 million entrepreneurs at an early stage, the 49 percent are men and 51 percent are women. 53 percent are between 18 to 34 years old, 40 percent between $35-54$ years and 8 percent between 55-64 years. 50 percent have completed high school education or above. $62 \%$ are married or living in common-law marriage. 51 percent are white [18]. The role of the loan officer not only as a seller or credit grantor, but also as advisor, appears to be critical for microfinance to become effective [9]. Often, information and suggestions from loan officers can help enable business entrepreneurs. One characteristic of the Brazilian labor market is that people tend to have more than one job to increase their income [27]. On the other hand, microentrepreneurs tend to overestimate the number of hours that really work, especially in the case when they use their home as the business location. In spite of this subject major part of entrepreneurs in Brazil, seek to open new business because of necessity and fundamental need.

In terms of responsibilities and be with payments on time, they pointed out some factors as determinants of default are micro-entrepreneurs with higher education degrees, male entrepreneurs and singles, businesses that have higher monthly revenue and operating income and companies operating with formal records are more likely to default compared to those without formal registration [28]. A minimalistic microcredit program might not be the most cost effective policy for reducing hardcore poverty [6]. Loans to the core poor are the riskiest, the costliest and the least effective in terms of core poverty reduction. Two 
factors can jointly stabilize the Brazilian microcredit, financial sustainability and social responsibility [11].

In 2014, to address the turnover of entrepreneurs, research opened 5 new tracks in the range of "up to $\mathrm{R} \$ 60,000.00 "$ ". It has been found with this detail that $51.1 \%$ of the initial entrepreneurs focused on billing range of up to $\mathrm{R} \$ 12,000,23 \%$ between $\mathrm{R} \$ 12,000$ and $\mathrm{R} \$ 36,000$ and $3.6 \%$ from $\mathrm{R} \$ 36,000$ and $\mathrm{R} \$ 60,000$ totaling $77.7 \%$ to $\mathrm{R} \$ 60,000$. Bureaucratic procedures constitute one of the most important obstacles in providing assistance to formal or informal small businesses and to reduce poverty.

The strong focus on financial guidance also helps microcredit to have a social transformation character, because it helps the entrepreneur to improve the performance of your business and develop it permanently [29]. Borrowers perform better in terms of livestock, participation in savings schemes and overall value of household assets [10].

\section{E. Impact of Microcredit on Poverty Relief}

After having analyzed the preconditions of microcredit's positive impact on poverty alleviation, we here explore how microcredits have effectively affected poverty in the case of Brazil. Between 1980 and 2013, Brazil' HDI value increased from 0.545 to 0.744 , an increase of 36.4 percent or an average annual increase of about 0.95 percent. Georgia and Grenada share the same rank (Human Development Report 2014). Based on Human Development Report of 2015, this index had a small growth about 0.011 resulting to a new value 0.755 in 2015 and put the country in $75^{\circ}$ place positioning it between 188 countries and territories. Brazil' HDI value for 2013 is 0.744 that positions the country at 79 out of 187 countries and territories. Has the positive impact of microcredit benefited different social categories in Brazil? While microcredit is an effective poverty alleviation tool for the less severe poverty cases, its impact to reduce core poverty is not evident. The positive correlation between borrower's income and gains from microcredit means that the poorer borrowers gain less than the relatively richer ones [6].

It is difficult to envisage a significant reduction of poverty through microcredit [30]. Even when they observe some data from two programs in this area, in Brazil, they can see the low coverage of this type of credit, in terms of the number of people served in the face of poverty in Brazil. Current economic crisis in the country has caused more unemployment and has affected even more the poor population. However, if microcredit is practiced in an isolated manner without articulating with the other policies for generating employment, work and income, productive inclusion, solidarity economy, support for small entrepreneurship and professional qualification, it will not be able to reach the objectives that are Propores [31].

\section{CONCLUSION}

We provided substantial responses to the paper's research inquiry relative to necessary preconditions and impact of microcredit on poverty eradication. Microcredit has contributed significantly to the mitigation of socioeconomic disparities in the country, through the generation of jobs and income but not to eradicate poverty.
Recent studies show that a large number of microcredit borrowers in Brazil are indebted and this is because they have not been successful in their business. It is a matter of concern that in some countries, even in Brazil, there are some institutions where microcredit policies are implemented, without the proper understanding of the actions necessary to achieve effective results in alleviating poverty and, consequently, promoting social inclusion [32].

Even if there is no statistical correlation between microcredit users and entrepreneurs, the data suggest that growth of entrepreneurs depends on the number of borrowers. The profile of borrowers is very similar to the profile of entrepreneurs specially when comparing income and geographical location. Offering social capital to the community provides the decision-making and the practice of actions involving collaboration and benefit to the whole community [4].

Microcredit certainly is a promising and suitable tool to fight the less poignant levels of poverty of millions of Brazilians. However, the belief that microcredit is a cure all to fight core poverty under appreciates the heterogeneity of the poor. Brazilian programs aiming to alleviate chronic poverty need to take a more complex perspective of what contributes to chronic poverty [6].

Although microcredit would be an effective means of reducing poverty, but its outcome depends on the economic condition and political situation of each country. Financial education and teaching of entrepreneurship techniques should be basic requirements for granting loans to the less educated population.

The lack of updated data and reports disclosed by the Brazilian government and also a few studies on microcredit in Brazil, to some extent made difficult to elaborate and analyze this study.

\section{REFERENCES}

[1] Human Development Report, United Nations Development Programme, UNDP, 2014.

[2] M. Yunus and A. Jolis, Banker to the Poor: Micro-Lending and the Battle Against World Poverty, New York: Public Affairs, 1999.

[3] D. Gurses, "Microfinance and poverty reduction in Turkey," PGDT, vol. 8, pp. 90-110, 2009.

[4] C. G. dos Santos and R. S. do M. Carrion, "Microcredit and poverty: A possible dialogue?" Revista de Administração Contenporânea, Curitiba, pp. 53-67, 2009.

[5] S. Shetty, "Microcredit, poverty, and empowerment: Exploring the connections," PGDT, vol. 9, pp. 356-391, 2010.

[6] M. Bosch, F. M. B. G. de. Nascimento, D. M. Zouain, G. de O. Almeida, "Microcredit in Brazil and its limitations as a core poverty alleviation tool," XXIII ENANGRAD, 2012.

[7] Ambrish, "Microfinance in India: Its issues and challenges," International Journal of Multidisciplinary Approach and Studies, vol. 1, no. 5, pp. 147-159, 2014.

[8] E. A. Araújo and C. U. de M. Carmona, "Efficiency of microcredit institutions: An application of DEA/VRS to the Brazilian case," Production, vol. 25, no. 3, pp. 701-712, 2015.

[9] R. A. da. Silva, "Microcredit and its relations with local development: A case study on the family bank," UFSC Universidade Federal de Santa Catarina. Centre of Socioeconomic, 2011.

[10] A. K. Ghalib, I. Malki, and I. Katsushi, "Microfinance and household poverty reduction: Empirical evidence from rural Pakistan," Oxford Development Studies, vol. 43, no. 1, pp. 84-104, 2015.

[11] W. Heloise, "Global politics of microfinancing poverty in Asia: The case of Bangladesh unpacked," Asian Studies Review, vol. 38, no. 4, pp. 544-563, 2014. 
[12] S. Herselman, "Creating meaning through microfinance: The case of the small enterprise foundation," South African Review of Sociology, vol. 45, no. 1, pp. 45-65, 2014.

[13] L. Bonoma, "Not only a poverty issue defining poverty assessment for microfinance institutions: A framework to discuss," Perspective on Global Development and Tecnology, pp. 392-417, 2010.

[14] M. Jayo, M. Pozzebon, and E. H. Diniz, "Microcredit and innovative local development in Fortaleza, Brazil: The case of banco Palmas," Canadian Journal of Regional Science/Revue Canadienne des Sciences Régionales, no. 1, pp. 115-128, 2009.

[15] P. R. A. de Souza, M. do C. Romeiro, and L. P. Bresciani, "Characteristics in microcredit offering in Brazilian program of microcredit in São Paulo state," Pensamiento \& Gestión, vol. 38. Universidad del Norte, pp. 77-94, 2015.

[16] N. Kabeer, "Conflicts over credit: Re-evaluating the empowerment potential of loans to women in rural Bangladesh," World Development, vol. 29, no. 1, pp. 63-84, 2001.

[17] Microfinance Barometer. 2016. [Online]. Available: http://www.convergences.org/wp-content/uploads/2016/09/BMFEN-FINAL-2016-Version-web.pdf

[18] Global Entrepreneurship Monitor, Entrepreneurship in BrazilExecutive Report, 2014.

[19] BACEN-Bulletin of Central Bank of Brazil, Report 2015

[20] D. M. Zouain and F. M. Barone, "Extracts on public policy of access to credit as a tool to combat poverty and social inclusion: Microcredit in the FHC era," Revista de Administração Pública, Rio de Janeiro, vol. 41, no. 2, pp. 369-380, 2007.

[21] G. Costa, "BOLSA FAMÍLIA raises the incomes of the extremely poor by almost 50\%," Agência Brasil, Brasília, Jun., 2010.

[22] F. M. Barone et al., "Introduction to microcredit," Council of the Solitary Community, Brasília, 2002.

[23] Series Financial Citizenship: Studies on education, protection and inclusion, Brasília: Central Bank of Brazil, 2015.

[24] F. M. Barone and E. Sader, "Access to credit in Brazil: Evolution and perspectives," Revista Administração Pública, vol. 42, no. 6, 2008.

[25] L. J. Filion, "Entrepreneurship: entrepreneurs and owners-managers of small businesses," Revista de Administração, vol. 34, no. 2, pp. $5-28,1999$.

[26] A. C. V. Lopes, C. B. Schulter, E. Binotto, S. de A. Andrade, and E. C. Busanelo, "Microcredit and microenterprises: A study in the Banco da Gente of mato grosso do sul," FACEF Pesquisa, Franca, vol. 14, no. 3, pp. 249-263, 2011.

[27] P. Aroca and J. Hewings, "Microcredit impact Assessment: The Brazilian and Chilean cases," Panorama Socioeconômico, vol. 27, no. 39, pp. 100-112, 2009.

[28] C. M. Alves andM. A. Camargos, "Factors determining default in microcredit operations," BASE, vol. 11, no. 1, pp. 59-73, 2014.
[29] Santander, A Brazil of Opportunities: 10 Years of Microcredit, pp. 1 40, 2013.

[30] V. de P. Colodeti and I. C. Leite, "Microcredit, informality and the fight against poverty," Temporalis, vol. 24, no. 12, pp. 385-406, 2012.

[31] M. de A. R. Domingues, "Productive microcredit as an instrument for poverty reduction: An evaluation of the experience of the Brazilian Northeast," Thesis: UNB, Brasilia, 2015.

[32] L. Alice and J. E. Ruppenthal, "Microcredit as an incentive to entrepreneurship at the base of the social pyramid," GEPROS. Gestão da Produção, Operações e Sistemas, vol. 7, no. 1, pp. 23-34, 2012

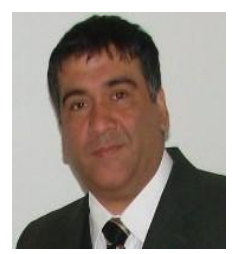

Mehran Ramezanali was born in Iran. Since 1987, he lives in Brazil. He obtained a bachelor degree in Business Administration from the Regional University of Blumenau Foundation - FURB in 1994 a master degree in business administration from Fundação Universidade Regional de Blumenau FURB in 2003 and holds a $\mathrm{PhD}$ in administration and tourism from the University of Vale do Itajaí UNIVALI. Presently he is a professor at the Centro Universitário para o desenvolvimento do Alto vale de Itajaí - UNIDAVI and coordinator of the Administration course. He has experience in the area of international business, marketing, market research and entrepreneurship.

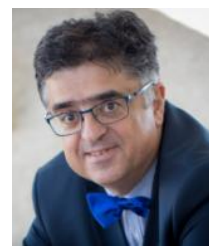

Djamchid Assadi is a higher education professor and researcher at Group Burgundy School of Business ESC Dijon, France. He obtaind a bachelor in business administration from International Management School E.S.C.P, École Supérieure de commerce de Paris, France $\mathrm{He}$ holds a $\mathrm{PhD}$ in marketing strategies and communication from Université de Paris IX Dauphine, France. He authored several books in French and published more than one hundred scholarly and professional articles in English and French. He is also member of several editorial boards publishing journal in English and French. Professor Djamchid ASSADI has delivered many lectures on business and marketing strategies. His research focuses on spontaneous relationships that new information technologies make possible to establish between individuals without intermediation centralizing organs such as, in particular, the crowdfunding industry. Regarding microfinance and financial inclusion, the central issue of Djamchid ASSADI of research is: how to serve the poor and non-banked? How to make the market for excluded become a profitable business for companies? The objective is to identify the conditions under which serve the excluded would be profitable for financial institutions. 